\title{
Acquiring Cherry Germplasm from Central and Eastern Europe
}

\author{
Amy F. Iezzoni ${ }^{1}$ \\ Department of Horticulture, Michigan State University, East Lansing, MI 48824
}

\author{
Additional index words. Prunus cerasus, Prunus avium, Prunus fruticosa
}

\begin{abstract}
The sour cherry (Prunus cerasus L.) industry in the United States is a monoculture of a 400-year-old cultivar from France named 'Montmorency'. To provide a solid germplasm base to breed alternatives to 'Montmorency', cherry germplasm was systematically collected over a 15-year period from its ancestral home in Central and Eastern Europe and introduced to the U.S. The strategy of germplasm collection using pollen, seed and budwood importation of highly quarantined species is discussed. Germplasm resulting from this effort is highlighted as well as an example of commercial success. Finally, the "recycling" of this immense germplasm collection to search for dwarfing precocious rootstocks for sweet cherry is described.
\end{abstract}

The sour cherry (Prunus cerasus L., syn. tart cherry) industry in the U.S. provides an example of an agricultural crop with extreme genetic vulnerability to disasters caused by pests, diseases and unfavorable weather conditions. Two factors which contribute to the potential vulnerability of agricultural crops are typified by sour cherry production: genetic uniformity and geographical concentration. The entire sour cherry industry in the U.S. is based on one cultivar 'Montmorency' (Iezzoni, 1988); and Michigan produces $75 \%$ of the nation's sour cherries. This monoculture provides an ideal environment for crop losses due to unfavorable weather or to disease and pest epidemics. Unfortunately, the vulnerability of this monoculture was realized in 2002. Spring freeze damage reduced sour cherry production to the lowest level recorded since 1945 (i.e., 2\% of a normal crop) (Kleweno and Matthews, 2003), with a devastating effect on the industry and economy of the fruit-growing regions. For example, northwestern Michigan annually produces an average of approximately 180 million pounds of sour cherries; yet, the 2002 production was only 3 million pounds (Kleweno and Matthews, 2003).

In addition to the genetic vulnerability of the 'Montmorency' monoculture, this 400year-old cultivar has numerous shortcomings. These include poor fruit firmness, the necessity to add sugar and red coloring to the majority of processed products, and susceptibility to an array of insects and diseases. The mission of the sour-cherry breeding program at Michigan State University (MSU) is to increase the profitability and environmental sustainability of sour-cherry production by developing new, cultivar-based opportunities.

Since sour cherry is not native to the U.S. and little diversity was represented among existing domestic collections, genetic improvement required the acquisition and use of genetic

Received for publication20 May 2004. Accepted for publication 27 June 2004. The financial support from the Michigan Agricultural Experiment Station and the following grower organizations to support the MSU cherry breeding and selection effort is gratefully acknowledged: Michigan Cherry Committee, Cherry Marketing Institute, Washington Tree Fruit Research Commission, and the Oregon Sweet Cherry Commission. The invaluable assistance of Renate Karle with the Russian and Ukrainian collaborations was greatly appreciated along with the technical assistance of Audrey Sebolt.

${ }^{1}$ To whom reprint requests should be addressed; e-mailiezzoni@msu.edu. variation from its native habitat, Central and Eastern Europe (Iezzoni et al., 1990; Vavilov, 1951). Also targeted for collection were the progenitor species of sour cherry, sweet cherry $(P$. avium L.) and ground cherry (P. fruticosa Pall.). In particular, sweet cherries were targeted, as it is a major fruit crop in the U.S., and its current production is also dominated by a few old cultivars. In addition, a minimal number of sweet cherry accessions $(\sim 70)$ are maintained at the USDA-ARS National Clonal Germplasm Repository for Tree Fruit/Nut Crops and Grapes, Davis, Calif. The strategies that were used to import cherry germplasm and some of the realized outcomes from this effort are described below.

\section{Cherry Germplasm Collection}

Area of Origin and Genetic Diversity. There are more than 30 species of cherries with most indigenous to Europe and Asia (Rehder, 1940). However, the main species grown for their fruit are in the Section Eucerasus which consists of the sweet cherry, sour cherry, and ground cherry. Ground cherry is a low-growing bush cherry native to Russia but present throughout much of Eastern Europe. Sweet cherry and ground cherry are presumably early derivatives of an ancestral Prunus (Watkins, 1976); whereas, sour cherry is believed to have arisen multiple times through natural hybridizations between ground cherry and sweet cherry (Beaver and Iezzoni, 1993; Brettin et al., 2000; Olden and Nybom, 1968). Since ground cherry is tetraploid $(2 n=32)$ and sweet cherry is diploid $(2 n=16)$, achieving tetraploid sour cherry and, therefore, fertile progeny requires an unreduced gamete from the sweet cherry parent. Unreduced pollen is present in sweet cherry (Iezzoni and Hancock, 1984) supporting the theory that sexual polyploidization was the likely mechanism of speciation.

As sour cherries spread throughout Europe, ecotypes evolved that differed in cold hardiness, tree habit and fruit and leaf characteristics (Kolesnikova, 1975). These ecotypes presumably arose in conjunction with continued gene flow between sour cherry and its progenitor species. For example, several cold-hardy sour-cherry cultivars grown in Russia and Eastern Europe are hybrids between sour and ground cherry. These selections are common in the cold northern ranges where sour and ground cherry habitats overlap. Individual trees resulting from crosses between sweet and sour cherry are so prevalent, particularly in the warmer areas of Europe, that they have been given their own common name, Duke cherries (Hedrick, 1914).

Sour cherry cultivars have further been classified into two groups based upon flesh and juice color (Hedrick, 1914). The amarelle types, of which 'Montmorency' is a member, have red skin but nearly colorless juice and flesh. Morello types, which have skin, flesh and juice ranging from red to deep purple, are mainly grown in Europe. The darker pigmentation of morello types reduces the need for synthetic colorants in processing. In addition, morello fruit generally show less wind whip, scald and bruising. Presumably the amarelle 'Montmorency' became the dominant U.S. sour cherry cultivar due to its productivity and adaptability to mechanical harvest and not due to its clear juice characteristic, as red dye is frequently used in 'Montmorency' products to enhance the red color.

\section{Implementation of Cherry Germplasm Collection Strategy}

Status of sour cherry germplasm in the U.S. The Cherries of New York, published in 1914, describes more than 250 sour cherry cultivars that existed in U.S. collections at that time (Hedrick, 1914). Most of the cultivars described are variants of 'Montmorency' or 'English Morello' (syn. 'Schattenmorelle'), a common northern European sour cherry landrace, plus selections of western European origins. A few of the selections listed were of Russian origin; however, there was a noticeable absence of germplasm from regions likely to be replete with diversity, including Turkey, Hungary, Romania, and the former Yugoslavia (Iezzoni et al., 1990). Concurrent with the rise of the 'Montmorency' monoculture, most selections described in The Cherries of New York were lost from U.S. collections in the half century that followed its publication. The sour-cherry breeding programs in North America located in Ontario, New York, and Minnesota, also had disappointing outcomes. The two cultivars bred at the University of Minnesota, 'Northstar' (Alderman et al., 1950), and 'Meteor' (Alderman et al., 1952), and the one clone released from the Cornell University program, 'Surefire' (Andersen et al., 2000), gained only limited homeowner interest in the U.S.

It was in this setting that the sour cherry breeding program at MSU was initiated in the spring of 1982. Present in the MSU collection at the time were a modest number of sour cherry 
cultivars, most of which were from the 'English Morello' landrace and an ample number of 'Montmorency' clonal selections. That first summer, evaluations of the fruits and trees were disappointing in that selections with fruit types significantly superior to 'Montmorency' were not identified. This resulted in the conclusion that U.S. sour cherry breeding would not be successful without a rapid infusion of superior germplasm.

"What this superior germplasm was and where it would be found, I did not know. However, the next spring, I set out to find it and bring it to the U.S."

Goals. An assessment of reported genetic diversity and active sour-cherry breeding programs clearly identified Eastern Europe as the target location (Iezzoni et al., 1990). Unfortunately, the political Cold War made communication and travel to eastern Europe extremely difficult. First-hand accounts of the pertinent institutions, breeders and breeding programs provided by Fred Hough, one of the few pomologists from the west to travel in this region, were invaluable. Travel funded by a grant from the U.S. Office of International Cooperation and Development, facilitated official approval by host-country institutions for a germplasm collection trip behind the Iron Curtain.

My initial cherry germplasm collection trips had two major goals: 1) assessment of genetic diversity and 2) germplasm importation. An assessment of genetic diversity was critical to predict the potential success of a breeding program and to identify productive geographic regions for germplasm collection. The second major goal, germplasm importation, was complicated by U.S. quarantine restrictions. Prunus budwood (including cherry) requires a lengthy screening process conducted by USDA-ARS scientists at the Plant Germplasm Quarantine Office, Beltsville, Md., in which the budwood is tested for the presence of certain virus and grafttransmissable infectious agents (Waterworth, 1993). This quarantine period can range from 3 to 8 years before the budwood is released with full approval from the U.S. Animal and Plant Health Inspection Service (APHIS). Fortunately, cherry pollen and seed do not require virus indexing. Therefore, germplasm importation was primarily accomplished using direct seed and pollen importation with only a small percentage of the germplasm being brought into the U.S. as budwood.

Pollen collection. The first collection trip was to Bulgaria, Romania, Hungary, and Poland and the former nation of Yugoslavia in the spring of 1983. This time was chosen so that pollen could be brought back to Michigan in time for pollinations. In consultation with the cherry breeders in these countries, travel was planned from south to north and timed to overlap with cherry bloom with a 1 week stay in each country. This permitted sufficient time for the discussion and travel required to assess the germplasm and to collect and dry the pollen. Arrangements were also made for budwood from certain accessions to be sent in February 1984 to the U.S. Plant Germplasm Quarantine Office. Traveling in the spring meant that fruit observations would be limited to sampling processed fruit. However, the sour-cherry collection at MSU was so uninspiring that there was little reason to intermate the existing selections. Therefore, the value of getting the pollen from superior germplasm to Michigan in time for crossing took precedence. The hospitality and kindness of the breeders and colleagues, who assisted with this effort, were overwhelming, and their kindness is acknowledged herein: Serbia, Asen Stancevic and M. Nikolic; Bulgaria, Vassil Georgiev; Romania, Vasile Cociu and Titu Gozob; Hungary, Janos Apostol, Sandor Brózik, and Pal Maliga; and Poland, Zygmunt Grzyb, S.A. Pieniazek, and Dr. Czynczyk.

Following bloom northward over a 5-week period provided an excellent opportunity to understand and observe the genetic variability present in sour cherry. In general, moving from south to north, the native sour cherry germplasm exhibited a progression from sweet cherry traits (upright tree, spur-fruiting habit, early bloom) in the south to ground cherry traits (bush form, fruiting on 1-year-old wood, late bloom) in the north. This range in plant form and bloom time spanned the differences between the two progenitor species and illustrated the importance of introgression in generating diversity in sour cherry (Beaver et al., 1995; Hillig and Iezzoni, 1988; Iezzoni and Mulinix, 1992). Kolesnikova (1975) documented this morphological diversity and grouped sour cherry into two ecotypes based on cold hardiness and, therefore, with likely level of genetic introgression with its progenitors.

The pollen from all selections collected was used in crosses on 'Montmorency' and 'Schattenmorelle'. These two cultivars represented the different ecotypes of sour cherry described by Kolesnikova (1975) and therefore were chosen as breeding parents and testers to generate full-sib and half-sib families. Progenies from these half-sib families and the individual full-sib families were used to determine parental breeding value and visualize phenotypic segregation.

Seed collection. Over the next 15 years, germplasm collection trips were primarily scheduled to overlap with fruit ripening with the majority of germplasm imported as seed. Seed collections trips were made to Hungary (Host: J. Apostol), Romania (Host: T Gozob), Russia (Hosts: E. Gigadlo, A. Kolesnokova, G. Eremin, Zukhov), Germany (B. Wolfram) and Sweden (Host: V. Trajkovski) and the resulting seedlings were planted at MSU's Clarksville Horticultural Experiment Station (CHES). Cooperative research projects with Hungary [1991-93, 1995-98] (Apostol et al., 1995), and Romania [1985-88], also supported visits for the European scientists to come to Michigan.

Budwood importation. Cherry budwood was only requested on a selected subset of the germplasm because of limited capacity for indexing by the USDA-ARS. The first sour cherry budwood that arrived at the U.S. Plant Germplasm Quarantine Office in1985 was released for propagation in the U.S. in 1990. By this time, progeny from these selections, generated with pollen collected in eastern Europe in 1983, were already fruiting and under selection in the MSU breeding program.

Targeted germplasm collection. The previous cherry collection efforts in Europe had the general objective of increasing the genetic diversity available in the U.S. for cherry improvement. More recently, targeted germplasm collection trips were undertaken to address specific needs.

The first targeted trip was a joint Prunus and Malus collection trip to Russia funded with a grant from the USDA-ARS, Plant Exploration Office. One of the goals of this trip was to obtain cherry germplasm for breeding disease-resistant sour cherry cultivars and dwarfing rootstocks for sweet cherry. In particular, cherry selections resistant to cherry leaf spot, caused by the fungus Blumeriella jappii (Rehm) Arx, were sought. This disease is the most severe sour cherry disease in the major humid production areas of the world (Mink and Jones, 1996), and host-plant resistance is a common goal of both the U.S. and Russian breeding programs. Russia was chosen as an area for collection because of the presence of two wild tetraploid cherry species, ground cherry and P. maackii Rupr., that could be searched for disease resistance. Additionally, Russian scientists had used individuals from these wild tetraploid species in crosses with sour cherry in attempts to introgress leaf spot resistance into sour cherry (Zhukov and Kharitova, 1983). Expanding the gene pool of sour cherry by crossing with related tetraploid cherry species as opposed to crossing with diploid cherry species is preferable because it avoids the roadblock presented by a sterile triploid $\mathrm{F}_{1}$

The second targeted trip was to the Ukraine. The goal of this trip, funded by the USDAForeign Agricultural Service, Research and Exchange Division, was to attempt to insure that the germplasm in an important Ukrainian breeding collection was not completely lost. At risk was the breeding collection from the 50-year cherry breeding career of Liliya Taranenko, at the Donetsk Branch of the Institute of Horticulture in Donetsk, Ukraine. The Ukraine is a rich center of cherry diversity, has a long history of successful cherry breeding, and no Ukrainian sweet or sour cherry germplasm had previously been imported into the U.S. The volume of material in Taranenko's sweet and sour-cherry breeding program was overwhelming, as she has evaluated over 35,000 seedlings and selected about 3,000 advanced selections. The cherry parental material used by Taranenko (1993) did not include western cultivars; yet, her breeding goals were very similar to mine. Because the germplasm of interest included advanced selections, it was necessary to protect the intellectual property rights of the Ukrainian breeders. A Memorandum of Understanding for testing was signed by the appropriate authorities at the Donetsk Branch of the Institute of Horticulture and MSU. Using dollars wired to her, the elderly Taranenko personally took her budwood on the long train trip from Donetsk to Kiev. Once in Kiev, she delivered it to the designated recipi- 
Table 1. Prunus germplasm collected between 1983 and 1998 in central and eastern Europe with novel useful characteristics. The selections are $P$. cerasus unless otherwise noted. All these selections except R1(1) are available from the PGRU. R1(1) is available directly from the author.

\begin{tabular}{|c|c|c|}
\hline Type of characteristic & Novel characteristics & Selections \\
\hline \multirow[t]{4}{*}{ Fruit quality } & High soluble solids content $(\sim 20 \%)$ & Érdi Jubileum \\
\hline & High anthocyanin content ( $\sim 6$ times that of Montmorency) & Dropia, Sarandi, Steinsbar, Pozog \\
\hline & Firm fruit & Crisana, Pándy, M209 \\
\hline & Large Fruit & Érdi Botermo \\
\hline \multirow[t]{4}{*}{ Bloom and ripening time } & Late bloom time & Pitic de Iasi $(P$. cerasus $\times P$. fruticosa hybrid $)$ \\
\hline & Short fruit development period (late blooming and early ripening) & MSU I 24 (63) \\
\hline & Very early ripening & Korai Pipacs Meggy \\
\hline & Very late ripening & Pitic de Iasi $(P$. cerasus $\times P$. fruticosa hybrid $)$ \\
\hline \multirow[t]{3}{*}{ Vegetative characteristics } & Fruit almost exclusively on spurs & MSU I 13 (61), Maliga Emléke \\
\hline & Propagates easily by hardwood or softwood cuttings & Sumadinka \\
\hline & Dwarf tree habit & Pitic de Iasi $(P$. cerasus $\times P$. fruticosa hybrid $)$ \\
\hline \multirow{3}{*}{ Diseases } & Resistant to cherry leaf spot & R1 (1) (Sixth generation from P. maackii) \\
\hline & Tolerant to cherry leaf spot & Oblacinska, Northstar, Csengodi Csokros, I 13 (61) \\
\hline & Tolerant to Prunus necrotic ringspot virus and prune dwarf virus & 26e 2 (7), 26e 2 (9) (P. fruticosa selections) \\
\hline
\end{tabular}

ent, Larry Panasuk, the Agricultural Counselor at the time at the U.S. Embassy in Kiev, who placed it in a diplomatic pouch bound for the U.S. State Department. The following e-mail message was received from Panasuk on 26 Feb. 1999.

"Amy, Just to advise that a precious elderly lady (76 years old today) brought the packet of sweet and sour cherry cuttings to the office. She packed it here in the office. My wife will wrap it further in paper for mailing and it will be in the pouch departing Thursday Feb 25...

P.S. The lady says that she herself has been working on cherry breeding for 50 years. She was not confident that the preservation of her work would continue under the harsh economic conditions now existing in Ukraine and suggested that maybe in 20 years folk in Ukraine would be requesting a reverse exchange to bring back some of the successful breeding material."

Most Ukrainian cherry germplasm is still in U.S. quarantine as many of the selections had to have heat-therapy treatment to remove viruses. Once the set of material is released from quarantine, virus-clean budwood will be sent back to the Ukraine, not only to replace any lost selections as Taranenko requested, but to help the establish Ukraine's first cherry virus-free budwood orchard.

\section{Outcomes}

Establishment of the USDA-ARS Sour Cherry Germplasm Collection. By the early 1990s, the cherry germplasm maintained at MSU's CHES exceeded 10,000 seedlings resulting from pollen and seed importation. Fields at CHES had to be removed to make space for planting the next generation of cherry seedlings. Therefore, in 1995, the USDAARS Plant Genetic Resources Unit (PGRU), Geneva, New York, added sour cherry to their list of curated species. Collaboration between MSU and PGRU resulted in the transfer of seedling and clonal selections that would form the basis of their new collection. These selections were chosen to represent a wide range of ecogeographical and morphological diversity (Table 1). Selections are being added as novel types and new germplasm are imported. Descriptors were developed and recorded for these accessions, and DNA fingerprints for many the sour-cherry accessions were obtained and deposited at the collection web site [http://www.ars-grin.gov/gen/tartchssr. html] (Cantini et al., 2001).

Germplasm Characterization: The germplasm collection effort created tremendous opportunities for genetic improvement in cherry. Particularly exciting is the opportunity to develop sour cherry cultivars with superior fruit quality, such as high soluble solids content, increased anthocyanin content, firm fruit, and a dry stem scar (Chandra et al., 1992; Iezzoni et al., 1990; Krahl et al., 1991; Wang et al., 2000)(Table 1). For the most part, my colleagues and I have found these traits in germplasm from landrace varieties that had been selected over hundreds of years by local gardeners and maintained by clonal propagation. The fruit of some of these types is so similar to sweet cherry that it is likely that these selections are derived from at least one sour cherry $\times$ sweet cherry backcross.

Freeze tolerance. During the night of 21 Apr. 2002, freezing temperatures reduced the Michigan sour cherry crop to only $2 \%$ of a normal crop, exposing a serious vulnerability of the 'Montmorency' monoculture. Would cultivar diversification have prevented this dramatic crop loss? To address this question, wood was collected on 22 Apr. 2002 from a planting at MSU's Horticultural Research Station, Traverse City, Mich., which included 'Montmorency' and 21 other sour cherry selections (Table 2). The death of flower buds and of pistils within damaged flower buds was recorded from each selection. None of the 'Montmorency' sour cherry buds examined was dead. However, when individual flowers within the live buds were dissected, $98 \%$ of the 'Montmorency' flowers had dead pistils. Two of the other cherry selections had $9 \%$ and $3 \%$ bud death. All the other selections except 'Érdi Nagygyumolcsu' were less damaged by the 22 Apr. freeze, suggesting that the nearly complete crop loss experienced in 2002 would have been greatly reduced if the industry had been growing an array of genotypes.

The mechanism underlying the seemingly unique susceptibility of 'Montmorency' pistils to the 22 Apr. freeze is not known. However, it is unlikely that floral phenology alone contributed to the tolerance of the other selections, as percent pistil death was not associated with bloom time (Table 2).

Disease resistance. Evaluation of the cherry germplasm brought back from Russiaidentified a seedling resistant to cherry leaf spot (Wharton et al., 2003). This plant, termed R1(1), is an open-pollinated seedling of 'Almaz', an interspecific rootstock variety bred at Michurinsk using $P$. maackii as the disease resistant parent (Zhukov and Kharitona, 1983). The original cross was made by I.V. Michurin between $P$. maackii and 'Plodorodnaya Michurina', a hybrid tetraploid progeny of a cross between sour and ground cherry. This seeding is currently being used as a cherry leaf-spot resistance donor in the MSU breeding program.

Commercialization of European selections. One of the landrace varieties collected in Hungary, tested and released in the U.S. through the MSU breeding program, is now in significant commercial production in Michigan. This selection, 'Ujfehertöi Furtös', sold as Balaton in the U.S. to protect intellectual property rights, has superior fruit quality compared to 'Montmorency' (http://www.hrt.msu.edu/balaton.html). Two other Hungarian sour cherry cultivars have also been commercialized in the U.S. in collaboration with MSU. These two cultivars, 'Érdi Bötermö’ and 'Érdi Jubileum', sold as Danube and Jubileum, respectively, in the U.S., have fruit qualities superior to Balaton and 'Montmorency'. However, since these cultivars are lower yielding than 'Montmorency' or Balaton, they may be mostly of interest to home gardeners. Funding received from the USDA-Foreign Agricultural Service, Foreign Currency Research Program, was critical to this commercialization process, as it funded trips of the Hungarian scientists to the U.S.

Initiation of a rootstock breeding program. By the mid 1990s, the MSU sour cherry breeding program had a large, diverse collection, most of which was derived from the importation of open-pollinated seed. The majority of the plants had already been evaluated for their cultivar potential, and the fields containing this germplasm were targeted for removal. At about this time, the two most influential breeders of dwarfing sweet cherry rootstocks, Hanna Schmidt and Brigitte Wolfram from Germany, were retiring, and their programs were not being continued. Schmidt felt that the most valuable species for breeding dwarfing cherry rootstocks were sour and ground cherry (H. Schmidt, personal communication), both of which were well represented in the MSU germplasm collection. Therefore, MSU cherry 
Table 2. Percentage of dead buds and dead pistils within live buds for 'Montmorency' and 21 sour cherry selections planted at the NW Research Horticultural Station, Traverse City, MI. The data were collected from branches cut from trees following a low temperature of $-2.8{ }^{\circ} \mathrm{C}$ on $21 \mathrm{Apr}$. 2002. Bloom date relative to 'Montmorency' is also presented.

\begin{tabular}{lccc}
\hline Selection & $\begin{array}{c}\text { Dead } \\
\text { buds (\%) }\end{array}$ & $\begin{array}{c}\text { Dead pistils within } \\
\text { live buds }(\%)\end{array}$ & $\begin{array}{c}\text { Bloom date relative to } \\
\text { 'Montmorency' (d) }\end{array}$ \\
\hline Montmorency & 0 & 98 & 0 \\
Meteor Korai & 0 & 76 & -6 \\
Érdi Nagygyumolcsu & 0 & 40 & -2 \\
Cigány 59 & 9 & 40 & 2 \\
Karneol & 0 & 32 & 2 \\
MSU II 7 (14) & 0 & 31 & 0 \\
MSU II 32 (27) & 0 & 28 & 1 \\
Balaton & 6 & 26 & 1 \\
Schattenmorelle & 0 & 22 & 2 \\
MSU 25 14 (20) & 0 & 22 & -1 \\
MSU 25 2 (29) & 0 & 20 & -6 \\
Cigány 404 & 3 & 17 & 2 \\
Danube & 0 & 15 & -3 \\
Kantorjanosi & 0 & 14 & 0 \\
MSU II 15 (3) & 0 & 12 & 0 \\
D076 & 0 & 9 & 1 \\
Dropia & 0 & 8 & 0 \\
MSU III 3 (38) & 0 & 3 & 1 \\
MSU II 6 (27) & 0 & 2 & -4 \\
MSU I 13 (61) & 0 & 2 & -1 \\
Malika Emléke & 0 & 0 & -3 \\
MSU 25 14 (23) & 0 & 0 &
\end{tabular}

germplasm was recycled before removal to search for selections with potential as sweet cherry dwarfing rootstocks. Those fields targeted for removal were left unsprayed for insects and diseases and the plants that were evidently the most cold hardy, disease resistant and tolerant to viruses were evaluated for ease of vegetative propagation. Those which could be easily propagated were saved. To date, 86 advanced selections from the MSU collection are currently budded and planted in trials in Michigan and Washington for evaluation as sweet cherry dwarfing rootstocks.

Challenges. The diversity present in sour cherry is the direct result of its polyploid origin and continued introgression with its wild progenitor species, coupled with a long history of human selection for diverse horticultural characteristics. However, this wonderful diversity did not come without a cost. As a result of chromosomal differentiation between its two progenitor species and complexity of its parentage, meiosis in sour cherry is typically irregular. Instead of exclusive bivalent pairing and euploid gametes, sour cherry chromosomes also can pair as trivalents and quadrivalents, resulting in aneuploid gametes (Hruby, 1962; Kotoman and Krylova, 1977; Manescu et al., 1980; Potemkina, 1973; Wang, 1998). When present in the egg, these aneuploid gametes result in abortion and poor fruit set.

In addition, although the sour cherry cultivars commercially grown worldwide are self-compatible; self-incompatible sour cherry individuals also exist (Lansari and Iezzoni, 1990; Redalen, 1984). In particular, many traditional landraces from Hungary and Romania that have excellent fruit quality are self-incompatible. This characteristic is unacceptable for commercial production. Self-incompatible selections require mixed plantings with pollinator cultivars that bloom at the same time as the main commercial cultivar, and sufficient bee populations to transfer the the breeders proudly revealed their successes to the west. This review would not be complete without an acknowledgement of the breeders and their key colleagues who have had such a positive impact on cherry improvement.

As the economic climate in eastern Europe and the Russian Republics improves, cherry breeding efforts are once again being revitalized, providing opportunities for U.S. researchers to collaborate and advance cherry breeding and genetics with a new generation of young scientists. Fortunately, knowledge of, and access to, cherry germplasm for the common good, is no longer a major limitation.

\section{Literature Cited}

Alderman, W.H., W.G. Brierley, S. Trantanella, T.S. Weir, A.N. Wilcox, J.D. Winter, K.W. Hanson and L.C. Snyder. 1950. Northstar cherry and Lakeland apple. Minn. Agr. Expt. Sta. Misc. Rpt. 11.

Alderman, W.H., W.G. Brierley, T.S. Weir, A.N. Wilcox, R.C. Blake, K. W. Hanson, and L.C. Snyder. 1952. Meteor cherry. Minn. Agr. Expt. Sta. Misc. Rpt. 16.

Andersen, R.L., J. Freer, and C. Choi. 2000. Cherries from Cornell breeding program. 15 Apr. 2004. http://www.nysaes.cornell.edu/hort/faculty/andersen/cherry_list3.html.

pollen (Westwood, 1993). Unfortunately, a large percentage of sour cherry hybrids are self-incompatible, even from crosses between self-compatible parents (Lansari and Iezzoni, 1990; Redalen, 1984). To help avoid this problem, an investigation of the genetic and molecular control of self-compatibility and self-incompatibility in sour cherry is on-going (Hauck et al., 2002; Yamane et al., 2001). To date, a self-compatible mutant allele has been identified and characterized in 'Érdi Bötermö' sour cherry (Yamane et al., 2003).

Excellent fruit quality has been achieved in the first generation from the crosses between 'Montmorency', 'Schattenmorello', and the European germplasm I acquired. However, due to meiotic irregularities and self-incompatibility limiting fruit set, it is only from the second generation bred from the original germplasm where self-compatible seedlings with cultivar potential have been identified. The potential is exciting and best illustrated by the advances made in soluble solids content (\%). The soluble solids content of 'Montmorency' is at most $15 \%$, while the soluble solids content of the sweet European sour cherries can reach 23\% (Apostol and Iezzoni, 1992), equivalent to values in sweet cherry. Second generation MSU seedling selections were identified with an unprecedented soluble solids content of $26 \%$ ! Certainly, the genetic variation is present, and the potential is more than could be imagined!

\section{Epilogue}

The friendship and assistance of dedicated European cherry breeders and their colleagues over the years formed the backbone of the cherry germplasm acquisition effort. Many of these scientists began cherry breeding after World War II using native germplasm collected from local villages. Their efforts were hidden during the Cold War, but in the 1980s and 1990s
Apostol, J. and A. Iezzoni. 1992. Sour cherry breeding and production in Hungary. Fruit Var. J. 46:11-15.

Apostol, J., K. Veghelyi, A. Iezzoni, and A.L. Jones. 1995. A cooperative program between Hungary and Michigan (USA): Breeding of disease resistant sour cherry cultivars for resistance to cherry leaf spot (Blumeriella jaapii). Uj Kertgazdasag 1/2:1-3.

Beaver, J. and A.F. Iezzoni. 1993. Allozyme inheritance in tetraploid sour cherry (Prunus cerasus L.). J. Amer. Soc. Hort. Sci. 118:873-877.

Beaver, J.A., A.F. Iezzoni, and C.W. Ramm. 1995. cherry. Theor. Appl. Genet. 90:847-852.

Brettin, T.S., R. Karle, E.L. Crowe, and A.F. Iezzoni. 2000. Chloroplast inheritance and DNA variation in sweet, sour, and ground cherry. $\mathrm{J}$. Hered. 91:75-79.

Cantini, C., A.F. Iezzoni, W.F. Lamboy, M. Boritzki, and D. Struss. 2001. DNA fingerprinting of tetraploid cherry germplasm using simple sequence repeats. J. Amer. Soc. Hort. Sci. 126:205-209.

Chandra, A., M.G. Nair, and A. Iezzoni. 1992. Evaluation and characterization of anthocyanin pigments in tart cherries (Prunus cerasus L.). J. Agr. Food Chem. 40:967-969.

Hauck, A., A. Iezzoni, H. Yamane, and R. Tao. 2002. Self-compatibility and self-incompatibility in tetraploid sour cherry (Prunus cerasus L.). Sexual Plant Reprod. 15:39-46.

Hedrick, U.P. 1914. The Cherries of New York. J.B. Lyon Company, Albany, N.Y.

Hillig, K.W. and A.F. Iezzoni. 1988. Multivariate analysis of a sour cherry germplasm collection. J. Amer. Soc. Hort. Sci. 113:928-934.

Hruby, K. 1962. Chromosome behavior and phylogeny of cultivated Cerasus. Preslia 34:85-97.

Iezzoni, A.F. 1988. 'Montmorency' sour cherry. Fruit Var. J. 42:74-75.

Iezzoni, A.F. and A.M. Hancock. 1984. A comparison of pollen size in sweet and sour cherry. HortScience 19:560-562.

Iezzoni, A.F. and C.A. Mulinix. 1992. Variation in bloom time in a sour cherry germplasm collection. HortScience 27:1113-1114.

Iezzoni,A., H. Schmidt, and A. Albertini. 1990. CherIsozyme diversity in sour, sweet, and ground 
ries (Prunus spp.), p. 110-173. In: J.N. Moore (ed.). Genetic resources of temperate fruit and nut crops. ISHS, Wageningen, Netherlands.

Kleweno, D.D. and V. Matthews. 2003. Michigan agricultural statistics 2002-2003. Mich. Dept. Agr. 2002 Annu. Rpt.

Kolesnikova,A.F. 1975. Breeding and some biological characteristics of sour cherry in central Russia. Priokstoc izdatel'stvo, Orel, Russia.

Kotoman, E.M and V.V. Krylova. 1977. Cytoembryological study of some sour cherry varieties (in Russian). Selektsiza i sortoizuch. Plodov. i Orekhoplodn. Kul'tur. 7:95-100. [Plant Breed. Abst. 49:5104; 1979]

Krahl, K.H., A. Lansari, and A.F. Iezzoni. 1991. Morphological variation within a sour cherry collection. Euphytica 52:47-55.

Lansari, A. and A. Iezzoni. 1990. A preliminary analysis of self-incompatibility in sour cherry. HortScience 25:1636-1638.

Manescu, C., N. Radulescu-Mitroiu, and M. Simionescu. 1980. Investigation into some embryological causes of infertility in sour cherries. Lucrari Stiintifice Institutul Agronomic "N. Balcescu", Horticultura 6:37-42. [Plant Breed. Abstr. 52:5177; 1982]

Mink, G.I. and A.L. Jones. 1996. Cherry diseases: Their prevention and control, p. 347-366. In: A.D. Webster and N.E. Looney (eds.). Cherries:
Crop physiology, production and uses. $\mathrm{CAB}$ Intl., Oxon, U.K.

Olden, E.J., and N. Nybom. 1968. On the origin of Prunus cerasus L. Hereditas 59:327-345.

Potemkina, G.A. 1973. Features of the formation of the female gametophyte in sour cherry varieties showing female sterility (in Russian). Tsitogenetich i. Tsitoembriol. Metody Selektsii Plodov. Yagodn. Kul'tur. [Plant Breed. Abstr. 47:1594, 1977]

Redalen, G. 1984. Fertility in sour cherries. Gartenbauwissenschaft 49:212-217.

Rehder, A. 1940. Manual of cultivated trees and shrubs hardy in North America. 2nd ed. Macmillan, New York.

Taranenko, L.I. 1993. Methodology for accelerated stone fruit breeding and variety tesing. Donetsk Branch of the Institute of Horticulture, Ukrainian Academy of Agricultural Sciences, Artemyevsk, Ukraine.

Vavilov, N.I. 1951. The origin, variation, immunity and breeding of cultivated plants. Ronald, New York.

Wang, D. 1998. RFLP mapping, QTL identification and cytogenetic analysis in sour cherry. $\mathrm{PhD}$ diss. (Mich. State Univ., East Lansing) Abstr. 99-2385.

Wang, D., R. Karle, and A.F. Iezzoni. 2000. QTL analysis of flower and fruit traits in sour cherry.
Theor. Appl. Genet. 100:535-544.

Waterworth, H.E. 1993. Processing foreign plant germplasm at the National Plant Germplasm Quarantine Center. Plant Dis. 77:854-860.

Watkins, R. 1976. Cherry, plum, peach, apricot and almond, p. 242-247. In: N.W. Simmonds (eds.). Evolution of crop plants. Longman, New York

Westwood, M.N. 1993. Temperate-zone pomology: Physiology and culture. Timber Press, Portland, Ore.

Wharton, P.S., A.F. Iezzoni, and A.L. Jones. 2003. Screening cherry germplasm for resistance to cherry leaf spot. Plant Dis. 87:471-477.

Yamane, H., K. Ikeda, N.R. Hauck, A.F. Iezzoni, and R. Tao. 2003. Self-incompatibility $(S)$ locus region of the mutated $S^{6}$-haplotype of sour cherry (Prunus cerasus) contains functional pollen S allele and non-functional pistil $S$-allele. J. Expt. Bot. 54:1-7.

Yamane, H., R. Tao, A. Sugiura, N.R. Hauck and A.F. Iezzoni. 2001. Identification and characterization of S-RNases in tetraploid sour cherry (Prunus cerasus L.). J. Amer. Soc. Hort. Sci. 126:661-667.

Zhukov, O.S. and J.N. Kharitona. 1983. Cherry breeding: results and prospects. Acta Hort. 140:91-93. 